\title{
THE AGRARIAN ECONOMY OF THE REGION OF ÉVORA IN THE FIRST HALF OF THE 17TH CENTURY (1595-1660): AN EXPLORATION OF MAIN INDICATORS
}

\author{
RUI SANTOS \\ Universidade Nova de Lisboa
}

\section{RESUMEN}

Este artículo intenta establecer la cronología y dinámica de la depresión del siglo xvir en la región de Évora, en el sur de Portugal. El examen de un conjunto de variables clave -estadísticas vitales, precios de alimentos y renta de la tierrasitúa el inicio de la depresión en la última década del siglo xvı, así como su continuación hasta 1660. Se detectan varios intentos de recuperación, pero todos ellos cortados por malas cosechas, a veces asociadas con epidemias y guerra. En conjunto, las alzas de precios de los alimentos aparecen asociadas con signos de depresión en las demás variables. Esto parece indicar que esas alzas venían dictadas por el comportamiento de la oferta, no de la demanda, pesando gravemente sobre los ingresos de la mayor parte de las familias, mientras que los campesinos resultaban incapaces de aprovecharlas.

Palabras clave: Évora, crisis del siglo XVII, crisis agrarias

\section{ABSTRACT}

This article tries to establish the chronology and dynamics of the $17^{\text {th }}$ century economic depression in the region of Évora, in Southern Portugal. By examining

\footnotetext{
${ }^{a}$ Faculdade de Ciências Sociais e Humanas, Departamento de Sociologia e Instituto de Sociologia Histórica. rsantos@fcsh.unl.pt
} 
a set of key variables -vital statistics, prices of foodstuffs and farm rents- the onset of the depression is located in the last decade of $16^{\text {th }}$ century, and its continuation up to 1660 is attested. A number of attempts to recovery are detected, but all of them were checked by poor harvests, sometimes joined by plague and war. On the whole, high prices of foodstuffs appear to be associated with signals of depression in the behaviour of other variables. This seems to indicate that these price increases were supply-driven, rather than demand-driven, weighting heavily on the incomes of most families, whereas small farmers were unable to take advantage of these seemingly favourable conjunctures.

Keywords: Évora, $17^{\text {th }}$ century depression, agrarian crises

JEL Classification: N13, N33, N53

\section{INTRODUCTION}

The subject of this article is the agrarian economy of a region in Southern Portugal, the region of Évora in the province of Alentejo, from the last few years of the 16th century to the second half of the 17th century, or, to be precise, 15951660. Although this largely transcends the life span of Don Quixote, it provides the minimum chronological breadth to frame the first quarter of the century in longer-term movements, and also to provide enough chronological depth for significant statistical relationships to be drawn from the data.

The region, like the province as a whole, has as a main agrarian feature the economic and social prevalence of large landed property, then mostly detained by aristocratic houses and by the Church and related institutions, municipal institutions and, at the provincial scale, by military orders. Farmland was structured in large units of hundreds of hectares, regionally known as herdades, which were at that time mostly let to farmers in short-term leases. Farming was already a largely commercialized activity, depending on hired labour and producing cereals and cattle, among other goods, for the market. Évora is the largest city in the Alentejo, commanding a large municipal territory in the heart of the province. It was the regulating market for Alentejo wheat, while at the same time its closeness to Lisbon and ecological conditions made the region an important cattle-raising centre for the capital. Around it several other municipalities can be aggregated in a sub-region with some character and internal complementarities ${ }^{1}$.

${ }^{1}$ See Silbert (1978, pp. 439-442). This work remains mandatory reading as the most accomplished historical-geographical description of Alentejo, as well as of other areas of mediterranean Portugal in the 18th and early 19th centuries. More detailed accounts of the region's main traits in some previous publications are given in Santos (2003, pp. 19-35 and 67-69), (2004a, pp. 383-385), and (2004b, pp. 23-26). 
The aim of the article is mainly descriptive, attempting to highlight the main dynamics of 17 th century economic depression in the region by looking at series of quantitative variables that may be said to constitute main indicators of economic performance of the sector, tempered when possible with relevant qualitative data. These are grouped under three headings that cover major dimensions of this agrarian economy, to wit: population (section 2), prices of staple agricultural products, namely wheat and meats (section 3), and farm rents (section 4). Besides the description, or rather the narration of the behaviour of the series, some exploratory correlations between them are essayed as a step towards hypothetical inferences, although no overall model is proposed.

\section{POPULATION}

To sketch the regional population trends in the period under consideration, one has to rely on rather scarce evidence. The 17th century recession will have to be set against the backcloth of 16th century growth, for which we can lean on one household count at the end of the first third of the century and a few souls counts clustered around 1590. Throughout the 17th century, however, I could find no reliable population counts, a few published figures being simply too vague and imprecise to be useful in any way for this purpose. The first reliable count for the region after 1593 dates from as late as 1720 . To fill in the gaps, I relied on a sample of rural parish records across the region of Évora. Unfortunately, there are few of them for the late 16th and the early 17th century, especially in what concerns burial records. Of those there are, two indexes were computed for baptisms and burials of over 7 years olds ${ }^{2}$.

The period studied in this article begins at the close of a steady population growth during the 16th century, in Alentejo as well as throughout the Country

\footnotetext{
${ }^{2}$ See Santos (2003, pp. 172-174) for a critical appraisal of available population counts; ibid., pp. 161-169 for a discussion of parish records, description of materials and methodology and annex 2 in cd-rom for basic data and indexes. Data for both indexes were drawn from a common set of 13 parishes. The baptisms index starts in 1595 with six parishes, to which one more is added in 1597, another in 1603, one in 1622, two in 1625, one in 1627 and yet another in 1641. The burials index begins in 1615 with eight parishes, although flawed data exist for seven of them before that year. One more is added in 1622, two in 1625, one in 1629 and another in 1645. Index bases were shifted according to sample composition, and all partial bases were reported to a common period, the same for baptisms and burials, when data on all parishes are simultaneously available. Because of the long-term research design governing data gathering and processing, the index bases are actually placed at a later period -base $100=$ average of the period 1675-1700-, which of course does not in any way affect the variation of the indexes. For final presentation, the burials index was weighted for the ratio between the bases -burials base/baptisms base $=0.452-$ in order to make the two vital series comparable.
} 
and indeed Mediterranean Europe, according to Braudel (1987, pp. 368-369). With different regional intensities and chronological nuances, recession seems to have settled across most of Spain in the late 16th or the early 17th century, reaching its bottom between the decades of 1630 and $1660^{3}$. In Extremadura, right across the border, baptism series began recessing by 1590 and stagnated until 1620, then fell abruptly until the $1660 \mathrm{~s}^{4}$.

Concerning Portugal as a whole, Godinho (1978, p. 391) opposed traditional accounts of decadence under Spanish rule, estimating that population had grown along the 16th century until close to the 1640 Restoration. Magalhães (1984, pp. 17-28 and 1083-1084) and Oliveira (1991, pp. 52-56) agree on 16th century growth, followed by a depressing phase somewhere in the first decades of the 17th century leading to population levels in 1639-40 close to those recorded in 1527-32. While the former author dates the trend inversion from the early 1620s, the latter dates it from the end of the 16th century, with some recovery until the 1620s, followed by a new downturn in the 1630s. Rodrigues (1993, pp. 212-214) agrees with an overall growth trend during the 16th century, although moderated by migration and sporadic epidemic outbursts, and also believes in a sharp drop at the very end of the 16th and the beginning of the 17th century to below the level of 152732 ; this would have been recovered by the end of the first quarter of the 17th century, leading to moderate net growth until 1640, relative to 1527.

At the regional level, in the Algarve, also in Southern Portugal, the long growth of the 16th century seems to have given place to a depressive phase from the early 1590s to the 1660s, but none of the household counts during the 17th century lends support to a population drop back to the levels of $1527-32^{5}$. Population increase is well documented for Alentejo during the last two thirds of the 16th century, and in all probability it had began earlier. Little is known, however, about the phases of this growth, as the documents so far explored provide data points in 1527-32, 1589, 1592 and 15936. Estimates in Santos (2003, p.190) and Fonseca

\footnotetext{
${ }^{3}$ See Brumont (1984, pp. 3-4 and 82-90); García Sanz (1986, pp. 50-86); García Sanz (1990, pp. 196-202); Gurría García (2004, pp. 73 and 769); Hernández García (2004, pp. 3233 and 36-37); Kamen (1983, pp. 39-59); Le Flem (1989, pp. 15-27 and 92-99); Llopis Agelán and Cuervo Fonte (2004, pp. 44 and 57); Nadal (1976, pp. 30-70); Salomon (1964, pp. 44-48)

${ }^{4}$ Rodríguez Grajera (1990, pp. 32-61).

${ }^{5}$ See Magalhães (1984, pp. 13-17).

${ }^{6}$ Numeramento..., 1527-32, Entre Tejo e Odiana, critical edition and study in Dias (1993); Archive of the Cabido da Sé de Évora, EE 22 GG, Relatio status ecclesiae elborensis [1589]; Numero das almas que tem este Arcebispado d'Évora... 1592, presentation, publication of data and study in Fonseca (2002-2003); Biblioteca Pública de Évora, Manuscripts (BPE), COD CXXVIII, fl. [289-292v], Relação do estado da Igreja Elborense q. da o ill.mo sñor Arceb.po de Evora ad visitanda limina apostolorum pello terceiro quadrienio [1593]. Argument for dating [1589] and [1593] in Santos (2003, p. 172).
} 
(2002-2003, p. 45) about population volumes in the archdiocese of Évora ${ }^{7}$, taken into account missing data in the latter's source, fairly converge to an annual growth rate estimate of around 0.60 per cent between 1527-1532 and 1592-1593; the former finds evidence of a deceleration at the end of the 16th century, from an annual growth rate of 0.63 per cent between 1527 and 1589 to one of 0.42 per cent between 1589 and 1593, which is only to be expected as the total reference volume had by 1589 increased by more than 50,000 souls over seven years old. Leaping across the 17th century to the earliest data point of the 18th, in $1720^{8}$ one finds a meagre annual growth rate of 0.12 per cent since 1593, an estimated growth of 28,000 souls (17 per cent) which in fact, when compared to baptism index average differentials between 1700 and 1720 (around 15 per cent), seems to be mostly a net result of 18th century growth, after late 16th century levels were finally recovered somewhere between 1685 and $1700^{9}$.

Seen from the region of Évora, the 17th century was in fact one of recession, aggravated by wartime crises in the 1660s, and followed by recovery since the $1670 \mathrm{~s}^{10}$. But using the 1720 to $1527-1532$ ratios of population and of average birth index levels as rough estimators, the result suggests that only episodically, in the most critical years of the end of the 16th century and of the 17th century -during and immediately following the crisis of 1637-, if at all, did population totals drop back to early 16 th century levels ${ }^{11}$.

Clouds of distress were gathering since the last years of the 16th century. The archbishop of Évora, D. Teotónio de Bragança, mentioned in 1599 «[...] great scourges of hunger, plague, and war with which Our Lord chastises us for so many years ${ }^{12}$. The reference to the three scourges was of course rhetorical, and to the extent that it had some empirical referent it was not necessarily confined to the region. The scourge of war, namely, had no direct relevance for Alentejo at that date. But as to hunger and «plague» -which might mean a wide range of lethal epidemics-, the scourges did strike home. At the national level, bad agricultural years from 1596 and successive plague outbreaks in 1598-1603 ${ }^{13}$ inaugurated the

\footnotetext{
${ }^{7}$ The archdiocese of Évora covered most of Alentejo, with the exception of two small dioceses in the north eastern border of the province (Portalegre and Elvas).

${ }^{8} \mathrm{BPE}$ COD CIX CIX/2-12, $\mathrm{n}^{\circ}$ 14, fls[29-38], Lista das Cidades villas, vigayrarias $e$ Freguesias que ha neste Arcebispado de Evora como tambem dos fogos, e pessoas que nelle ha no anno de 1720. See Santos (2003:175) for critical appraisal.

${ }^{9}$ See Santos (2003, p. 196).

${ }^{10}$ Santos (2003, p. 217-223).

11 Santos (2003, p. 203). In fact, sharp short-term drops in the baptisms index during critical, high mortality years may reflect drops in birth rates or rises in unrecorded mortality at birth, rather than lower population stocks.

${ }^{12} \mathrm{BPE}, \mathrm{COD} \mathrm{CIX} / 2-7 \mathrm{n}^{\circ}$ 12, Provision for the creation of the Brotherhood of St. Peter Martyr, 1/5/1599.

${ }^{13}$ Rodrigues (1993, pp. 220-222).
} 
recession. Judging from the records of the deliberations of the Chapter of Évora, «plague» alarms were most serious in 1599 and $1600^{14}$.

Indirect evidence of population decline in the earlier years of the 17th century comes in the form of disputes between interested parties competing for a depleted pool of tithe-payers and labourers in the parishes around the two main urban nuclei of the region. Measures were passed by two different archbishops in 1605 and 1612 threatening of excommunication the priests and all tithe related officials and collectors in Évora and Montemor, as well as landowners, farmers and stewards of the herdades who connived to entice people to switch residence between parishes by offering them cheaper houses, tithe credits or by any other means ${ }^{15}$. In the few rural parish registers recording burials that I could retrieve for this period in the region of Évora proper, mortality peaks stand out between 1595 and 1600, while the somewhat wider evidence concerning baptisms shows them at their lowest in 1597 and 1600; the index sketches a recovery up to 1606, slowly declining from then on, until in the 1620s they had fallen back to the lowest levels of 1595-1600.

\section{CHART 1}

\section{BAPTISMS AND BURIALS ( $>7$ YEARS OLDS) INDEXES AND 5 YEAR MOVING AVERAGES, 1595-1660 (See footnote 1)}

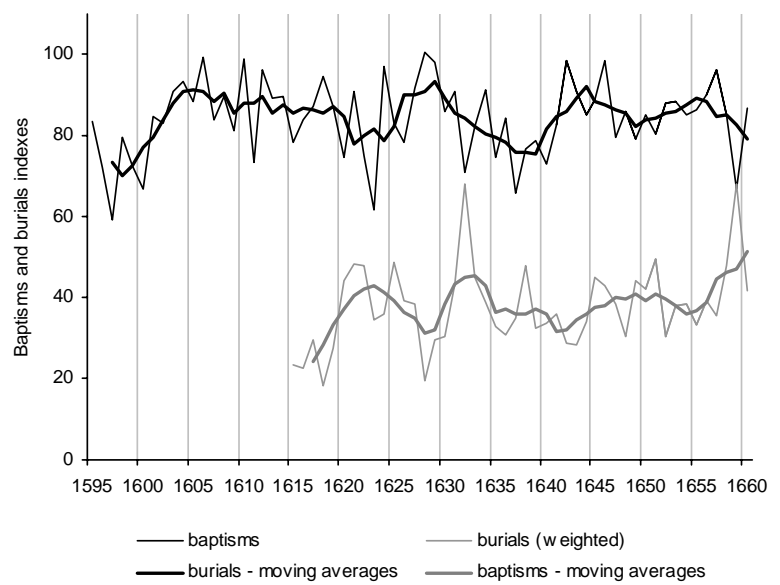

Source: Santos (2003).

${ }^{14}$ Anunciada (1893, p. 90); Ferreira (1893, p. 23); Lima (1986, pp. 60-70).

${ }^{15}$ Order by D. Teotónio de Bragança in 1605, cited as a precedent for a new decision to the same effect in 1781, BPE COD CIX/2-10, $\mathrm{n}^{\circ}$ 11; Order by D. José de Melo in 1612, BPE COD CIX/2-9. 
As a structural feature typical of ancien régime demography, throughout the series we can detect a roughly symmetrical pattern between baptisms and burials. In fact, there is a significant negative correlation between the two indexes ${ }^{16}$. The facts that this relationship accounts for only about 16 per cent of variance, and that the correlation and its significance threshold both decline when computed on 5 years moving averages point to the fact that this is mainly a short-term relationship reflecting extreme yearly variations, be they exceptionally good or bad years. Let us look in greater detail.

At the very start of our observation window, baptisms are already falling down while, as pointed above, mortality peaks are apparent in the few parishes for which there is evidence, in the wake of bad crops that raised wheat price in 1595-1596, making it necessary to buy wheat in Castile to provide for the city ${ }^{17}$. After 1600 , baptisms start a recovery with maxima in 1606 and 1610, which corresponds to a phase of moderate and stable wheat prices up to 1615. But the rest of the period is on average one of stagnation, in which a few maxima are but short lived backbounces from previous critical drops, never gaining definite momentum.

Two cyclical depressions marked these decades. The first dropped to a minimum of baptisms in 1623, with rises in burials in 1620-1622 and again in 1625. Although no sharp peaks are registered in wheat prices, there is evidence of hardship in wheat provision in 1618-1622, both in the documents of the Celeiro Comum ${ }^{18}$ and in city government records ${ }^{19}$. After a remission up to 1628-1629, the second depression stroke harder and longer, probably with cumulative effects, with baptisms minima in 1632 and, at a very low level, in 1637. Burials rose sharply in 1631-1633, coinciding with the most generalized mortality crisis of the Spanish interior, attributed to crop losses in 1630 and probable typhus sequels ${ }^{20}$; and again, though at a lower level, in 1638. Food scarcity was again such by the end of 1635 and the first months of 1636 that the Chapter of Évora took several steps to ensure grains supply for sale and assistencial actions on behalf of the poor, not just in the city but in the countryside as well ${ }^{21}$. These crises coincided with severe wheat dearth in 1630-1632 and in 1635-1637, the latter concomitant with serious riots in Évora.

The baptisms maxima of 1642 and 1646 marked a short-lived recovery, which was disturbed and then checked by mortality outbreaks in 1645-1646 and 16491651, again with wheat dearth in 1650 and 1651 . The new attempt at growth by the baptisms index with a maximum in 1657 was checked in 1659, with mortality climbing

\footnotetext{
${ }^{16}$ Pearson correlation coefficient of -0.4024 , significant at $\mathrm{p}<0.001$.

${ }^{17}$ Arquivo Distrital de Évora, Câmara de Évora (ADE-CE), livro 8, Vereações (proceedings of the city government), fl. $4 \mathrm{v}, 5 / 10 / 1596$.

${ }^{18}$ Godinho (1970, p. 160).

19 Santos (2003, p. 219).

${ }^{20}$ Pérez Moreda (1980, pp. 288-300).

${ }^{21}$ See Ferreira (1893, pp. 50-53).
} 
as high as it had in 1632, while wheat price again soared. The ravages of the Restoration War, which had been confined to border areas since 1640, stroke closer and became harder with army displacements, which were beginning to disrupt agricultural activities. On the other hand, more men were being carried away to war. In 1657, the Misericórdia had trouble giving dowries to poor deserving brides «because men were at the borders and they [the poor deserving maids] could not find with whom to marry ${ }^{22}$. From here on, things only got worst with the escalation of the war, and as our period ends we stand at the verge of a third depression that would last virtually until the end of the war in 1668.

Throughout the above description of the behaviour of vital series, I often mentioned short-term coincidences between drops in baptisms and/or rises in burials and dearth of wheat. These, however, only illustrate extreme variations, and do not make for a regular pattern. I will now briefly explore the relationships between vital series and basic foodstuff series in a more systematic way. Chart 2 plots the demographic data together with the price of wheat ${ }^{23}$.

\section{CHART 2}

\section{BAPTISMS AND BURIALS (7 YEARS OR OLDER) INDEXES AND PRICE OF WHEAT AND FIVE YEARS MOVING AVERAGES, 1595-1660 (reais per bushel)}

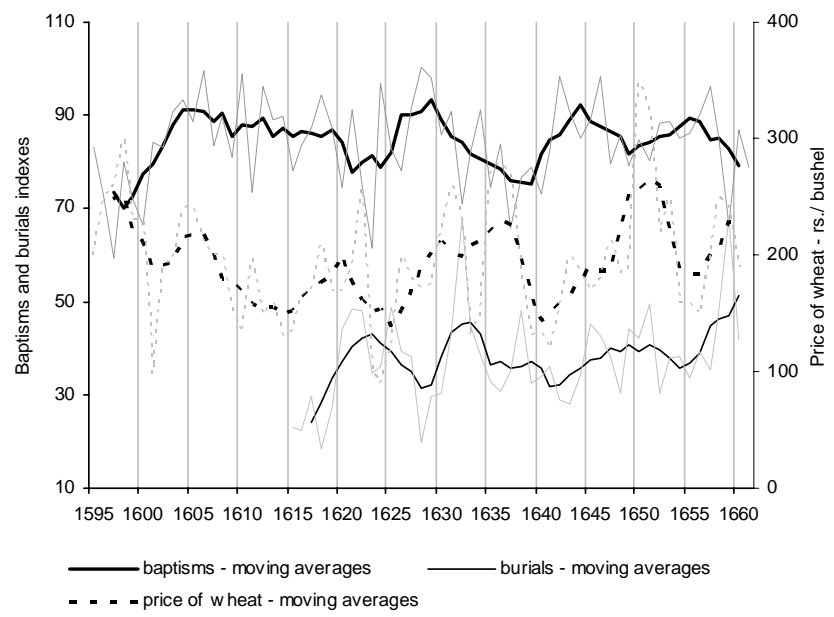

Source: Santos (2003).

\footnotetext{
${ }^{22}$ ADE, Misericórdia de Évora, livro 19, Lembranças, fl. 64 v.

${ }^{23}$ For information about price series, see section 2.1. below.
} 
There are clearly noticeable years when peaks or runs of dearth years coincided with either rises in burials, drops in baptisms, or both. But this is especially visible in critical years, and no one-to-one relationship is evident in the series. Is spite of the concomitances referred to above and which concern years of acute dearth, there are no significant correlations between yearly wheat prices and either baptism or burial index values. The relationships between the availability of basic foodstuffs and the vital series are in fact of a more cumulative nature, as can be seen by the rough parallelism of the moving averages of prices and burials, and their basic symmetry with those of baptisms. Crisis years apart, the relationships are conjunctural rather than annual and have to do with runs of good or bad years. These are best captured after cleaning short-term variation by using moving averages.

Charts 3 and 4 show the best-fitted regression curves between the 5 years moving averages of wheat prices and those of baptisms and burials indexes, respectively. There we find a weak but significant negative correlation between the medium-term cyclical fluctuations of the price of wheat and baptisms, and a rather stronger positive correlation between the former and those of burials.

\section{CHART 3}

\section{REGRESSION OF BAPTISMS INDEX ON PRICE OF WHEAT, 5 YEARS MOVING AVERAGES (reais per bushel)}

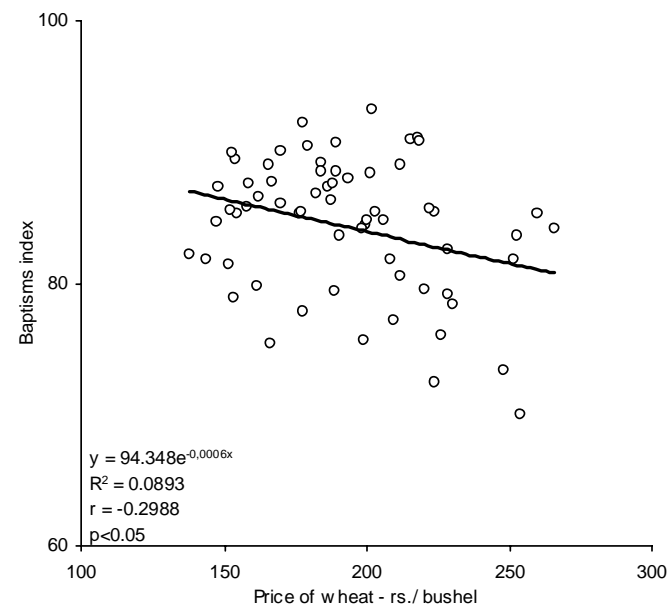

Source: Santos (2003). 


\section{CHART 4}

\section{REGRESSION OF BURIALS INDEX (7 YEARS OR OLDER) ON PRICE OF WHEAT, 5 YEARS MOVING AVERAGES (reais per bushel)}

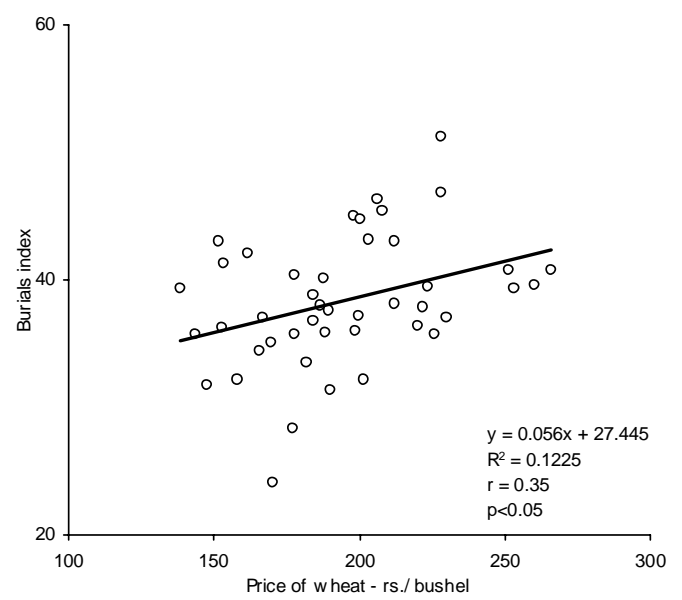

Source: Santos (2003)

Mortality was indeed more sensitive to the cumulative effects of dearth. After eliminating medium-term cycles by computing 11 years mobile averages on them ${ }^{24}$, we obtain a much higher and more significant correlation between long-term price and mortality cycles, as seen in Chart 5 . The same procedure yields no result when applied to baptisms; even though the slope remains negative, the correlation between the 11 years moving averages is not statistically significant. Thus, although both vital variables were sensitive to sporadic, acute dearth, systematic relationships with cereal prices are cumulative and conjunctural rather than shortterm, and they are stronger over a longer term in the case of mortality.

\footnotetext{
${ }^{24}$ See Godinho (1955, pp. 159-161).
} 


\section{CHART 5}

\section{REGRESSION OF BURIALS INDEX (7 YEARS OR OLDER) ON PRICE OF WHEAT, 11 YEARS MOVING AVERAGES (reais per bushel)}

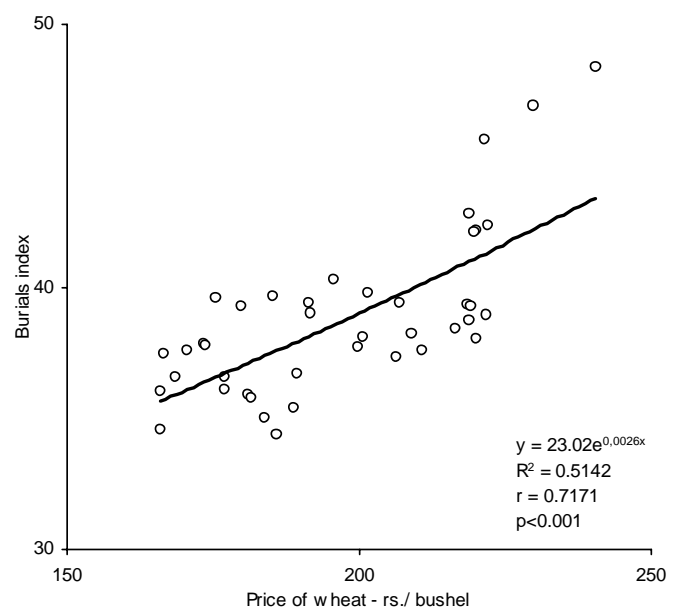

Source: Santos (2003).

Another relevant variable quite apart from price levels is short-term price volatility. It can be argued that whereas stable price increases per se may be virtuous, in the sense of the physiocrats' bon prix, if they are demand-driven and the producers can rely on the supply of factors -among which previous year's seeds stocks, and labour-, high short-term price instability, besides being negative in itself because of uncertain returns to producers' investments, signals recurrent crop failures in which high prices are shortage-driven and related to short-term collapse of labour demand, undermining the earnings of significant segments of wage-dependent population just when such earnings were most needed. Thus, high price volatility may have a stronger impact on population than high prices by themselves. Chart 6 shows the evolution of baptisms and burials together with the moving variation coefficient of wheat prices over 5 years. It seems clear at a glance that the more depressive phases in vital series do tend to coincide with periods of mounting price volatility. This is not surprising in the light of what we have just seen concerning the conjunctural effect of price levels on both vital series. 


\section{CHART 6}

\section{BAPTISMS AND BURIALS (7 YEARS OR OLDER) INDEXES AND FIVE YEARS MOVING AVERAGES, AND 5 YEARS MOVING VARIATION COEFFICIENT OF PRICE OF WHEAT, 1595-1660}

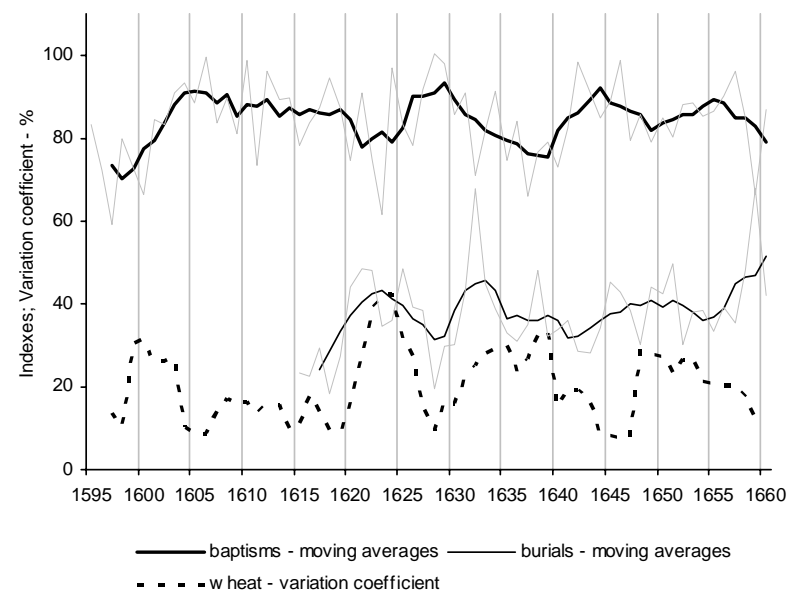

Source: Santos (2003).

Correlations confirm that price volatility has an effect on both baptisms and burials. This is true even for yearly values of both series, while no significant correlations emerge between prices and either vital series on a yearly basis ${ }^{25}$. Besides being more pertinent because of the statistical nature of the variables, the relationships are actually stronger with the 5 years moving averages of baptisms and burials, as shown in charts 7 and 8 .

${ }^{25}$ Correlation coefficients are -0.305 with yearly baptisms and 0.293 with yearly burials, both significant at $\mathrm{p}<0.05$. 


\section{CHART 7}

REGRESSION OF BAPTISMS INDEX ON WHEAT PRICE VOLATILITY, 5 YEARS MOVING AVERAGES AND VARIATION COEFFICIENTS

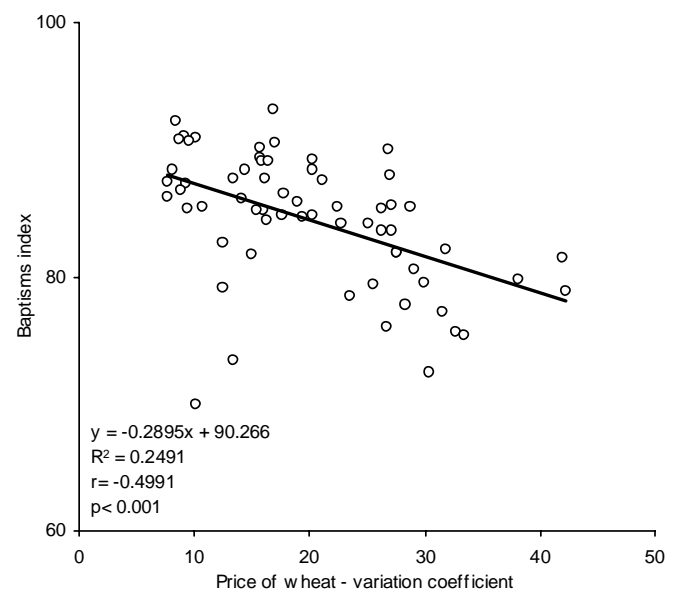

\section{CHART 8}

REGRESSION OF BURIALS INDEX ON WHEAT PRICE VOLATILITY, 5 YEARS MOVING AVERAGES AND VARIATION COEFFICIENTS

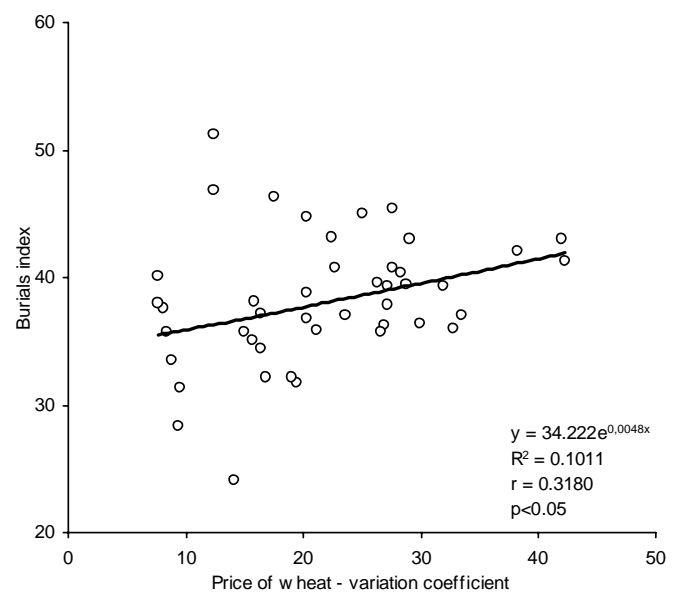

Source: Santos (2003). 
We can see that in spite of considerable dispersion around the lower values of the independent variable, both correlations are statistically significant. The relationship is both stronger and more significant with baptisms than with burials. Indeed price volatility correlates significantly higher with baptisms that did the averaged price levels (Chart 3), while in the case of burials the effect is slightly lower. It is tempting to look at the negative correlation with baptisms as evidence of some kind of preventive check operating through runs of difficult years, but it may as well be the effect of malnutrition and disease related fertility checks, or unrecorded births because of deaths at birth.

\section{PRICES}

The evolution of agricultural prices in Évora will be looked at through series of yearly wheat prices using August as the reference month ${ }^{26}$, and of yearly pork and mutton prices, as sheep and pigs were the main components of regional cattle farming $^{27}$. One significant setback concerning the prices of animal produce is the lack of wool prices. Urban retail meat prices provide the only indicator to guide us through the market conjuncture for cattle. Other economically important prices that are yet to be systematically collected for this region are those of wine and, especially, olive oil. Agricultural wages are also terra incognita and will probably remain so for want of sources. For the time being, we will have to do with what descriptive indicators we hold, while waiting for further archival work to fill in the blanks.

\subsection{Wheat}

Wheat prices, along with those of other grains, were collected from transaction records at the Celeiro Comum (common granary) of Évora -liquidations of debts incurred in wheat, normally for seed- and at the Misericórdia of Évora -grain sales and liquidations in cash of rents stipulated in kind. The final result is a composite series of actually recorded prices and of regression estimates based on intercorrelations between the series collected for each cereal in different documentary sources and between cereals, which have proved very reliable ${ }^{28}$.

${ }^{26}$ See Godinho (1955, pp. 11 and 111-112); Godinho (1970, p. 102), and Justino (1981, pp. 37-39).

${ }^{27}$ See Silbert (1978, pp. 624-631, and 702).

${ }^{28}$ For methodological details, basic data, intermediate steps and final series 1595-1850, see Santos (2003, pp. 72-104 and annex 1.1, cd-rom). Series of the Celeiro Comum as published in Godinho (1970, pp. 159-165). 
Wheat was the main staple in regional agriculture and the leading cereal in farming rotations, except in worst soil. In Évora the prices of the three major types of grains -wheat, barley and rye- are very much intercorrelated within the frame period of this study ${ }^{29}$. Therefore, wheat prices will be used to draw the general evolution of the conjuncture of grain prices.

\section{CHART 9}

\section{PRICE OF WHEAT, 1595-1660: AUGUST PRICES IN ÉVORAAND 5 YEAR MOVING AVERAGE (reais per bushel, logarithmic scale), AND 5 YEAR MOVING VARIATION COEFFICIENT (per cent points)}

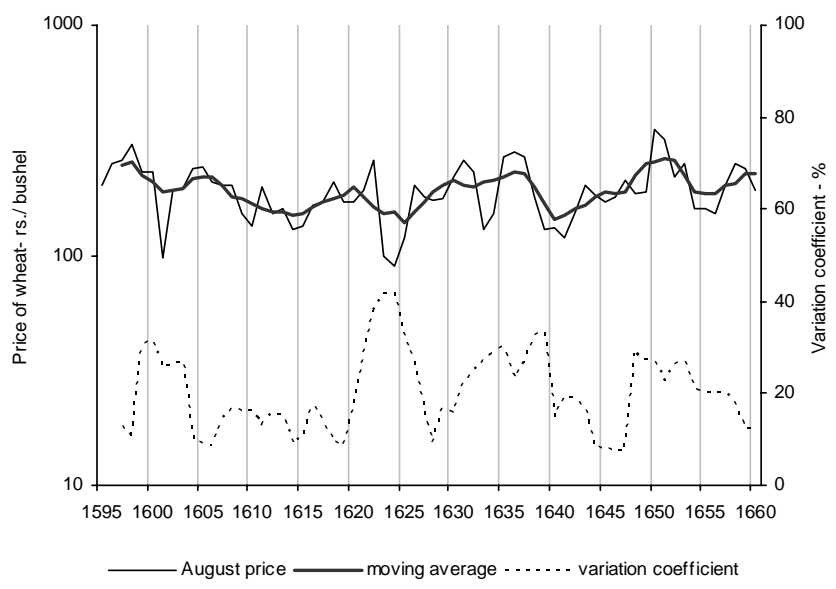

Source: Santos (2003).

Chart 9 shows the evolution of wheat prices over the period under study. Overall, there was a descending trend until the mid-1620s, giving place to a moderately increasing trend until the dawn of the 1660s. From rather high levels at the end of the 16th century, there was a clear downward slope up to 1624, with relatively moderate short-term instability; the variation coefficient remains well below 20 per cent most of the time. A closer look distinguishes two phases: the

${ }^{29}$ Correlation coefficients of 0.847 with rye and 0.813 with barley. Coefficients were computed between transaction prices actually recorded in August or, when missing, September or October each year. Estimates for missing years were not used in the correlations. Both correlations are significant at the 0.001 level. 
regular descent until 1615, and a sharp climb leading to the shortage crisis in 1622, followed by the no less sharp drop to the lowest sequence of 1623-1625. The second phase already inaugurates a period of higher price instability along two ascending cycles, cut by the cyclical depression around 1640 . The very irregular medium cycle 1625-40 fuses two short cycles, with high price peaks in 1630-32 and 1635-37 due to shortage crises and high variation coefficients. Along this sequence of crises, protest movements took place which came to be labelled «hunger riots», most violent and politically visible in the Évora upheavals in 1637, related with tax aggravation ${ }^{30}$. The following medium cycle (1641-1654) began with a relatively moderate and stable increase up until 1647, then climbing in 1651-52 to crisis prices above the highest levels that had prevailed at the close of the 16th century and subsiding afterwards until 1656.

Rather than an economically virtuous «phase $A$ » of a growth cycle, the price increase trend that succeeded the early 17th century depression after 1624 is in fact the aggregate result of a sequence of unstable short and medium cycles propelled by harvest shortage crises, and since the mid-1640s by the Restoration War against Spain, which would aggravate during the 1660s until peace came in 1668. It is small wonder that we find no trace of a sustained price increase driven by population growth and supported by increasing labour force. In fact, inasmuch as some relation does exist between medium term population growth and wheat prices, it is rather the reverse: as noted above (Chart 3), there is a significant negative correlation between the baptisms index and the logarithm of wheat prices, after cleaning short-term variation.

\subsection{Meats}

Meat prices were drawn from the records of annual contracts between Évora city government (Câmara) and an officially acknowledged group of butchers, who raised or bought live cattle that they fattened enjoying grazing rights privileges controlled by the local authorities, for the supply of meat in the city's regulated market in a controlled competition environment. As such these were not «free market» prices, not less because they were subject to hard political bargaining, often overtly turning to coercion, depending of a variable balance of power between the parties. In April 1618, for instance, the butchers who had refused to commit for the price proposed by the Câmara were forced to slaughter and sell all cattle found in their possession for that same price, after the Câmara had granted an exceptional general license to sell meat in the city thus increasing

\footnotetext{
${ }^{30}$ Fonseca (1995-1996); Magalhães (1976); Serrão (1967, pp. xliv-xlv).
} 
THE AGRARIAN ECONOMY OF THE REGION OF ÉVORA IN THE FIRST HALF OF THE 17TH...

competition in the short run as a means of pressure. In July 1630, for the same reason, they were forced to enrol all heads they possessed, which were embargoed at the Câmara's will, and they were forbidden to deal in cattle within municipal territory until they complied: that same month, one after another all butchers committed to sell beef and mutton for the stipulated prices. And in February 1622 the butchers were even arrested and forced to kill a number of cows and sell their meat the very same day. But while this institutional framework certainly increased price stickiness in the short term, it could not prevent prices to reflect the supply and demand variations in the medium term, as these variations directly impacted on the relative bargaining power of the butchers versus the city government. Besides group-enforced solidarity, butchers' resistance to imposed prices ranged from diverting supply to the underground private market, to the harassment of out-group competitors, and to simply running away across municipal borders ad offering their trade to other towns in the region, as a couple of them did in $1652^{31}$.

The degree of success of these forms of resistance was contingent on how much demand was unmet by legal offer alternatives, creating opportunities in competitive underground markets with price differentials, which reached 20 per cent plus tax-evasion in rarely precise cases recorded in 1648-1649, after the Câmara had tried to curb soaring prices during the previous years ${ }^{32}$. The possibility to embargo cattle was limited, and while it could be used as a short-run means of pressure during negotiations, it could hardly provide for a regular supply that was the primary aim of the city government. Opening up the market to private uncommitted traders, if pursued indefinitely, would in the end disrupt the whole institutional structure and its political regulatory power, which was entirely based in corporative contracting. Coercive pricing had as a short-term limit the economic viability of the butchers' trade and their ability to move across markets; when the limit was stepped on, price control would feedback on quantity, quality and regularity of supply. Much as the Câmara strived to control the meat retail market, price increases in production eventually reflected, albeit with some delay and rigidity, in institutional prices, as the behaviour of the series itself demonstrates ${ }^{33}$.

The trend of meat prices, as opposed to that of cereals, was definitely upward throughout the period under scrutiny, as may be seen in Chart 11, and indeed would remain so well into the 18th century.

${ }^{31}$ ADE, Câmara de Évora, Vereações: livros 11, fls.50v-51 and 55v-57; 12, fl.89v; 14, fls.78-80; 19, fls. 109-110.

${ }^{32}$ ADE, Câmara de Évora, livro 18, Vereações, fls.106-106v, 114, 162, and 172.

${ }^{33}$ For a long-term sociological analysis of the institutional framework and its evolution, methodological details and final series 1595-1850, see Santos (2003, pp. 120-145 and annex 1.2 , cd-rom). 
CHART 10

PRICES OF MUTTON AND PORK IN ÉVORA (reais per arrátel) ${ }^{34}$

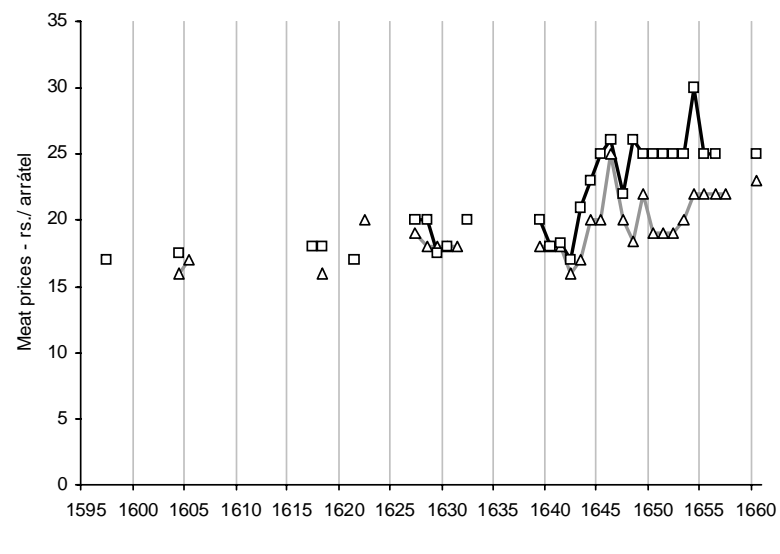

Source: Santos (2003).

The sparse evidence provided by the municipal records during the first quarter of the 17th century suggests that the prices of both meats remained fairly stable, with a moderate ascending slope, until the end of the 1630s, briefly curbed in 164142. The real de água tax which was imposed in 1635, doubled in 1641 and then doubled again in 1650, seems to have had scarce impact in the evolution of prices to the urban consumer ${ }^{35}$, as the city government fought to keep them as low as possible and probably forced the tax on the butchers. The sharp climb that raised the prices of both meats by over 50 per cent between 1642 and 1646, no doubt came in the wake of the troop settlements and of the first military operations and razzia warfare of the Restoration War that disrupted production in the more exposed areas in the region, as they did across the border ${ }^{36}$. From here on the prices of the two meats diverged, as pork kept close to that level for the rest of the period while mutton rapidly subsided to a platform slightly above the level it had attained by the end of the 1630s. But both consistently gained ground as compared to wheat, a trend that was steeper for pork, only losing some of those relative gains during grain shortage episodes (Chart 11). This, along with wheat

\footnotetext{
${ }^{34}$ Arrátel: ancient measure of weight corresponding to about $0.5 \mathrm{Kg}$.

35 Santos (2003, pp. 146-147).

${ }^{36}$ Marín Barriguete (1991, pp. 195-207); Rodríguez Grajera (1990, pp. 142-145).
} 
price instability, may have encouraged farmers to some shift toward cattle and grazing grounds, especially before the spread of war increased the risk of raids -by either foe or friend-; but there is as yet no evidence against which to test this hypothesis.

\section{CHART 11}

\section{PRICES PER ARRÁTEL OF MUTTON AND PORK INDEXED TO 3 YEARS MOVING AVERAGES OF PRICES PER BUSHEL OF WHEAT}

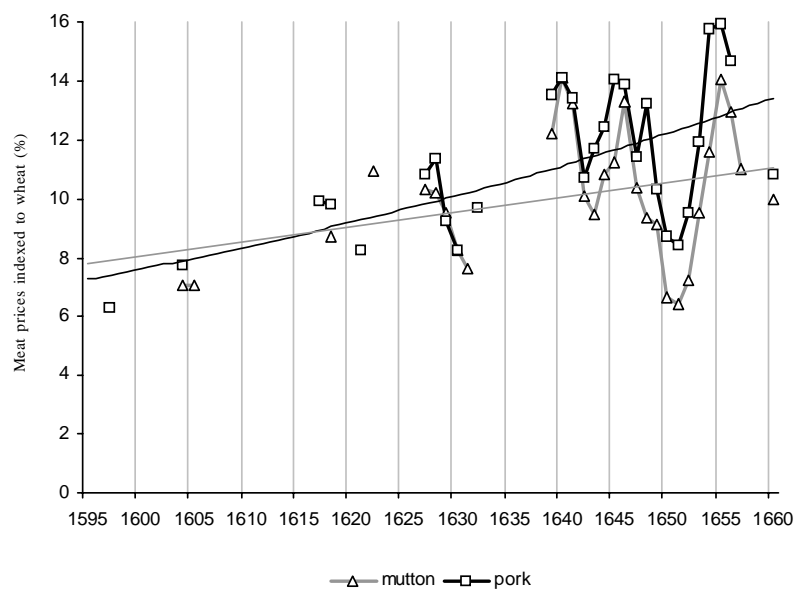

Source: Santos (2003).

\section{FARM RENTS}

In an agrarian economy such as that of Alentejo, where access to land structured in large farms was mainly mediated by short-term lease contracts, the variation of rent levels obtained by the herdades is a crucial indicator of economic conjuncture. Rents were usually stipulated in kind, for fixed amounts of reference cereals -wheat, barley and rye-, although often liquidated in cash; but a few were stipulated in cash. Sometimes, but not often, herdades shifted between contracts from one form of payment to the other. Rents in kind were almost invariably due in August 15th, while rents in cash were usually due in two instalments -December 25th and August 15th. Leases mostly lasted four, sometimes five years. The lease contracts transferred to the farmer the rights to the fruit of the soil during the 
contracted number of harvest years, according to customary rotation, plus herbaceous and arboreal pastures and, where relevant, to the fruit of the olive groves if not otherwise stipulated. Farmers acquired no rights to fixed capital, namely to fallen trees or their branches except in the necessary measure for the keeping of the groves, and severe penalties punished misdemeanour. Lease contracts also commonly imposed obligations on the tenant to improve the capital, often by creating and nurturing specified numbers of young trees -helm-oaks and olive trees- out of spontaneous bush.

There was a marked tendency for lease renewal to satisfactory farmers an even to their heirs, which however did not at all preclude rent increases by direct negotiation if demand for leases was high; frequently, such renewals took place after auction, but this was not necessary to ensure that market conditions were taken into account when negotiating leases ${ }^{37}$. The size and relative dispersion of the supply support the assumption that a large landowner's specific leasing policy could not deviate much from market trends, either in rent levels or in contractual arrangements. Although contractual rent was, with very few exceptions, fixed throughout the term of the lease, institutional risk-sharing devices were in place to protect the tenant in case of crop failures, ranging from total or partial rent arrears to partial rent acquittals. In severe hardship years, as farmers threatened judicial impugnation of the contracts under general law or sometimes just plain run away without paying, acquittals could rise to sizeable proportions of the contracted rent. This reflected not only the farmers' economic hardship, but also the surviving farmers' higher negotiating power, as landlords felt their future income threatened if the herdades were left untenanted and demand for leases dropped. Thus, besides contractual, or «nominal rent» we have to deal with another economic variable, more sensitive to short-term fluctuations, which I have labelled «effective rent» and defined as nominal rent subtracted of yearly rent losses ${ }^{38}$.

Rent data were collected from a sample of herdades of which the Misericórdia of Évora held at least a share in rent. The Misericórdia is a charitable institution created in 1499, whose resources largely depended of rents and rent shares in herdades, mainly in the surrounding region. Because of its heavy and relatively rigid expenditure, it depended both on the volume of its rents and on their stability. Its bookkeeping records tell of the expected and actually received incomes and of relevant decisions and events, such as unpaid rents and acquittals. I was able to collect from surviving records information about the evolution of rents for a set of up to 31 herdades, for a much longer period than the one analysed here. This

${ }^{37}$ The same is noted for large farm leases in Northern France by Hoffmann (1991, p. 225), and Moriceau and Postel-Vinay (1992, pp. 100-101).

${ }^{38}$ See Santos (2003, pp. 294-344) for a detailed account of the institutional framework and lease management practices in the region during the ancien régime. 
set, however, is only complete after 1650 . Thus, the indexes used in this study rely on a variable number of herdades ranging from 16 at the very beginning to 31 in the end of the period; all herdades present in any given year are a subset of the full sample of 31 . Chart 12 shows the distribution of the number of considered herdades over the years. For most of the period under observation, the indexes stand for a subset of 20 to 25 farms, occasionally broken by gaps in documentation. The output is internally consistent and there is no correlation whatsoever between variations in either the number or the subsets of included herdades and the behaviour of the indexes ${ }^{39}$.

\section{CHART 12}

NUMBER OF HERDADES INCLUDED IN RENT INDEXES PER YEAR, 1595-1660

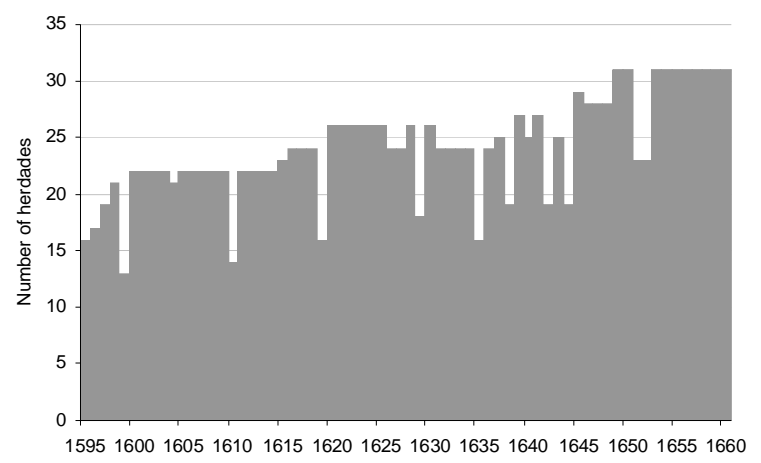

Source: Santos (2003)

The series were operationalized by converting rents in kind to cash using the year's August prices, and then deflating all cash values into their equivalent in wheat bushels, again at the year's price. Because of the longer-term perspective of the research this article relies on, the base 100 for each herdade is the average of nominal rent in 1670-1689, over which both nominal and effective rent indexes were computed case by case. The aggregate rent index for each year is the simple

\footnotetext{
${ }^{39}$ Out of the 31 herdades, only 5 do not correlate positively and significantly with the effective rent index. 18 correlate at significance level $\mathrm{p}<0.001$, with correlation coefficients ranging from 0.414 to $0.765 ; 2$ correlate at $\mathrm{p}<0.01$, with coefficients of 0.321 and 0.723 ; finally, 6 correlate at $\mathrm{p}<0.05$, with coefficients from 0.270 to 0.592 .
} 
arithmetic average of the indexes of all herdades present in that year ${ }^{40}$. Chart 13 plots the final results.

\section{CHART 13}

NOMINAL AND EFFECTIVE RENT INDEXES, 1595-1660

(average of nominal rent 1670-1689=100)

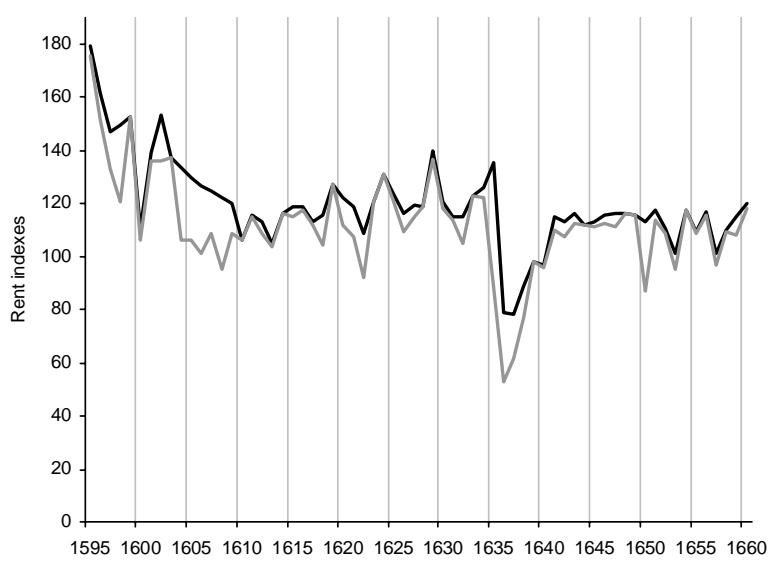

- nominal rent $\longrightarrow$ effective rent

Source: Santos (2003)

The descriptive outcome is quite straightforward. At the end of the 16th century, in spite of the difficulties that were already amassing, the high level of nominal rent still reflected the high demand for land of years not long gone, related to population pressure under the prevailing conditions of access to land. At the close of the 16th and the earlier years of the 17th century, several cases are documented of herdades partitioned among two, three and even more independent lease contracts. In later years, as population outgrew that of the late 16th century, appropriation of land became geared towards concentration and such levels of rent would never again be recorded. But neither would attain such levels of rent

${ }^{40}$ See Santos (2003, pp. 345-349, annex 3 in cd-rom) for further detail, basic data and processed data up to the final indexes. Again, the choice of the index base outside the studied period only affects the absolute values of the index and not its variations or its relations to other variables, which are at stake here. 
THE AGRARIAN ECONOMY OF THE REGION OF ÉVORA IN THE FIRST HALF OF THE 17TH...

losses as those the landlord suffered up to 1610, while trying to cling to obviously unrealistic contractual rents. 1595-1608 is a period of fast recession in nominal rent, followed by what by now is a familiar pattern of remissions and crises: some recovery until 1619 checked by depression in 1622, and a new but more unstable spurt, broken in 1632 and definitely collapsed in 1635-1637. Recovery from the latter crisis was achieved by the early 1640s, but stagnating at a lower average level than that in the years preceding 1635, and entering a new unstable period from 1650 on, which, like in preceding variables, can be related with hardening war with Spain. In 1657, for the first time, plunder by soldiers was invoked for to sustain a petition for rent acquittals in herdades of the Misericórdia located within the municipality of Évora, whereas in former years that had only happened in areas close to the Spanish border. The same year, the city government reported to the Crown that there were many herdades in its territory without farmers for fear of the enemy ${ }^{41}$. The worst was yet to come, but the recessive trend is already clearly established, as are its phases during the first half of the 17th century. Again the decade 1610-1620 appears as a brief remission period, and the crises of the early 1620 s and of the mid-1630s stand out as crucial depressive moments. I will now turn to the relationships of farm rent with the previously analysed variables on population and prices.

Starting with baptisms and burials indexes, Chart 14 plots them along with the effective rent series, and the respective 11 years moving averages. The reason for this longer averaging period is that it is only at this level of long-term trends that some correlations emerge with vital series, an then only with baptisms. In spite of some coincidence between the major demographic crises and falls in rent -which can probably be better explained in terms of the antecedent phenomenon of harvest failures as captured by wheat dearth, as we shall see below- and the known fact that decline in population preceded the sharp fall in rents from 1595, most yearby-year co-variation and even mid-term cyclical variation appear to be random.

${ }^{41}$ ADE, Misericórdia de Évora, livro 19, Lembranças (proceedings of the directing board), fls. 82-83; ADE, Câmara de Évora, livro 21, Vereações, [fls. not numbered], 4/8/1657 


\section{CHART 14 \\ EFFECTIVE RENT INDEX, BAPTISMS INDEX AND BURIALS INDEX AND 11 YEAR MOVING AVERAGES, 1595-1660}

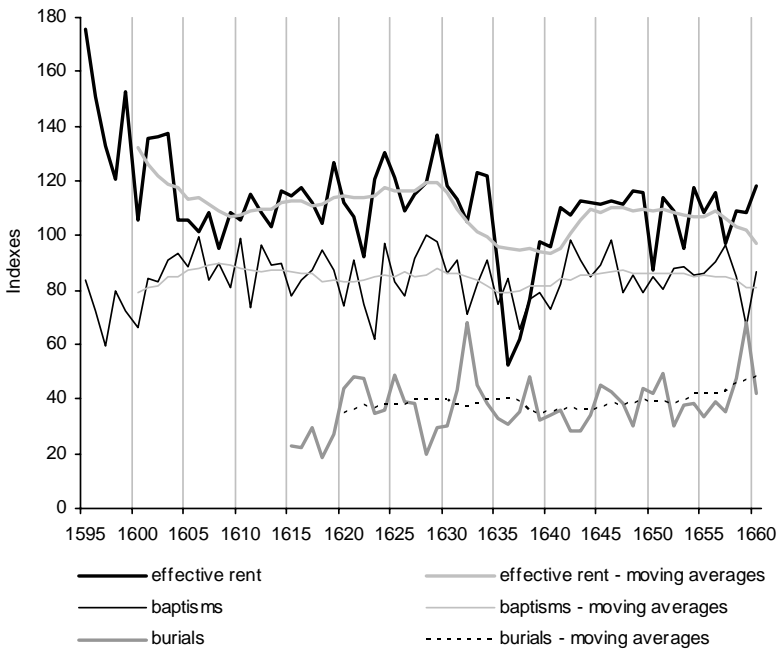

Source: Santos (2003).

In longer-term trends, population growth does correlate significantly and in a positive way with the evolution of rents, in spite of the noise caused by the remnants of high rents in 1595-1597, as baptisms were already declining (Chart 15). In fact, once the three outlying points on the top left side of Chart 15, plotting the averages centred in 1600-1602, are drawn from the correlation, it greatly improves in intensity and significance ${ }^{42}$. Thus, even within the context of the 17 th century depression, population recovery operating through demand for land appears to have retained a significant influence, in the long run, on the behaviour of land rent.

${ }^{42}$ The correlation coefficient rises in this case to 0.6321 , significant at $\mathrm{p}<0.001$. 


\section{CHART 15}

\section{REGRESSION OF EFFECTIVE RENT INDEX ON BAPTISMS INDEX, 11 YEARS MOVING AVERAGES}

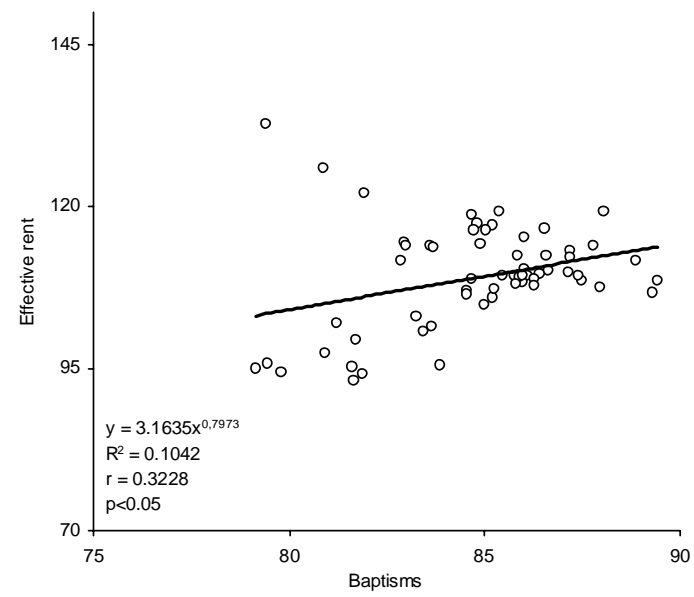

Source: Santos (2003).

The short-term behaviour of rents, on the other hand, was mostly dependent of the yearly economic outcome of agricultural units, which was severely hampered by bad harvests, as captured by wheat prices. Chart 16 draws an eloquent picture showing how much price peaks, signalling crop failures, impacted negatively on the yearly levels of effective rent. This is partly a reflection of rent acquittals, and partly of subsequent drops in nominal rent, especially after particularly bad single years or runs of poor harvests. It is also visible that the periods of rent recovery and relative stability tend to coincide with those of lower price volatility. 


\section{CHART 16}

EFFECTIVE RENT INDEX AND WHEAT PRICE

(reais per bushel and 5 year moving variation coefficient)

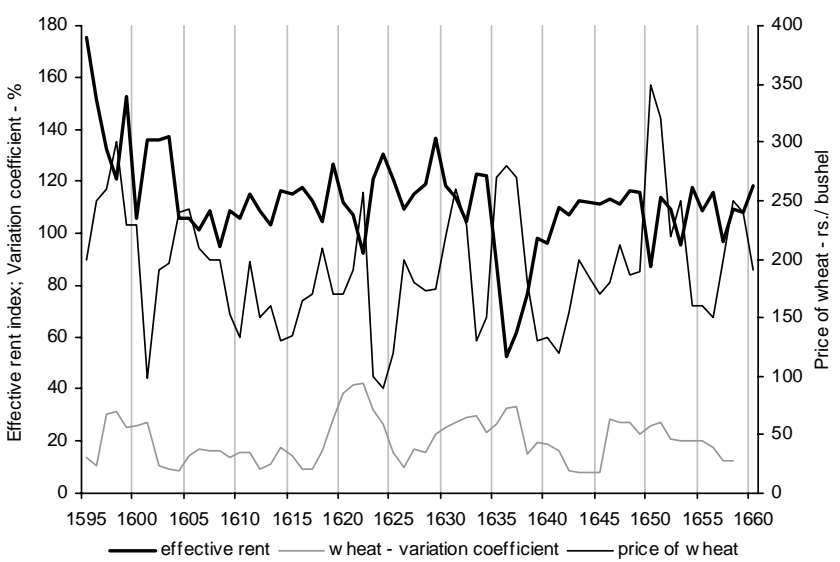

Source: Santos (2003).

These conclusions are made clearer by the regressions plotted in charts 17 and 18, which show not only a significant negative correlation between yearly wheat prices and the effective rent index, but also an even higher and more significant negative correlation between percent short-run variation of the two variables, irrespective of price levels, which shows that effective rent very consistently tended to increase when prices decreased. 


\section{CHART 17}

REGRESSION OF EFFECTIVE RENT INDEX ON PRICE OF WHEAT, YEARLY VALUES 1595-1660

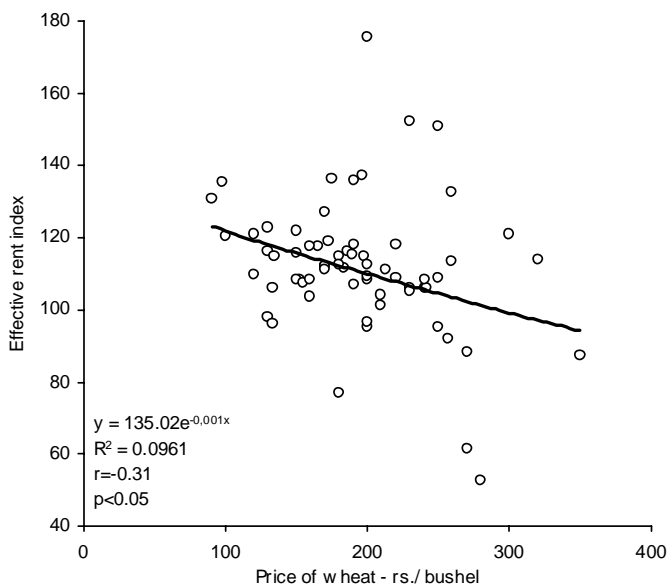

Source: Santos (2003).

\section{CHART 18}

REGRESSION OF PERCENT VARIATION OF EFFECTIVE RENT INDEX ON PERCENT VARIATION OF PRICE OF WHEAT, YEARLY VALUES 1595-1660

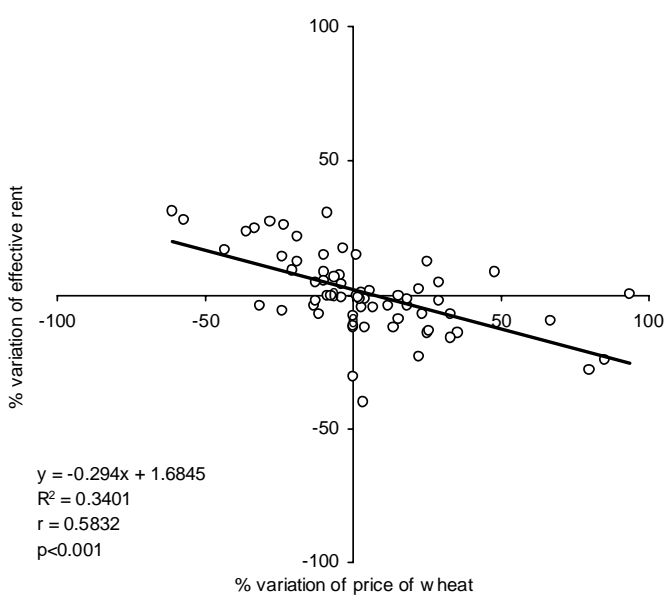

Source: Santos (2003) 
Clearly, high prices were not an incentive for land rent, even in an agrarian economy as commercialized as that of Évora. No significant correlation emerges at medium and long term; the effects of prices on rents seem to have been wholly short-term ones during this period.

\section{CONCLUDING REMARKS}

After the series for main indicators of the performance of the regional agrarian economy have been presented and commented, the emerging picture is that of a recessive but dynamic first half of the 17th century. The recessive trend can be dated back to the last years of the 16th century, closing the long post-medieval period of growth, following dearth crises and disease outbreaks that brought baptisms down to an absolute minimum in 1597 and farm rents to a sharp drop until 1609. A few healing conjunctures were systematically disrupted by further crises; the role of critical sequences -1621-1622, 1631-1632 and 1635-1638- in checking incipient recovery dynamics was highlighted, as well as the effects of intensified warfare after 1650, which were but the prelude to the worse years of war in the 1660s. Crises operated through the connections of poor harvests and food dearth, sometimes joined by infectious disease, negative dynamics in demographic series, and farmers' economic distress indicated by drops in effective and nominal rents.

Patterns of relationships between the series were explored and discussed. One such emerging pattern is that wheat price levels and instability tended to have a depressing effect, if any, on the other variables. Rather than a demand-driven stimulus to the economy, soaring prices signal economic hardship to producers as well as to consumers. The fact that there is no evidence of a depression in prices over the whole of the period, therefore, can be misleading for the interpretation of economic behaviour as a whole. Especially noticeable is the strong negative short-term effect of price level and volatility on farming rents. High and unstable prices resulted from bad harvests, and most farming units at this time apparently did not had the means to profit from higher prices, which indicates that they could not amass enough grain stocks to transfer from good to bad years. My pet hypothesis is that such capacity would depend on increases in farming scale and in the economic and social status of farmers, along with lower rent pressure ${ }^{43}$. But this is a tale of the 18th and 19th centuries; the ingenious hidalgo had long been dead by then.

\footnotetext{
${ }^{43}$ See Santos (2003, pp. 379-382 and 390-395), and Santos (2004b).
} 


\section{REFERENCES}

Anunciada, D. J. DA (1893): «Extracto da noticia dos livros e papeis archivados nos armarios, bancos e gavetas da aula capitular da sé d'Evora, feita por D. João da Anuncuada em 1847». Archivo Eborense (11-14).

Braudel, F. (1987) : La Méditerranée et le monde méditerranéen à l'époque de Philippe II. Paris: Armand Colin, 2 vols. (8th ed.).

Brumont, F. (1984): Campos y campesinos de Castilla la Vieja en tiempos de Felipe II. Madrid: Siglo Veintiuno.

DiAs, J. J. Alves (1993): Gentes e espaços (em torno da população portuguesa na primeira metade do século XVI). Lisboa: Universidade Nova de Lisboa, Faculdade de Ciências Sociais e Humanas. (3 vols.) (doctoral thesis, mimeo).

Ferreira, A. Martins (1893): «Apontamentos extrahidos dos 'livros dos accordos' do archivo capitular da Sé d'Evora pelo dr. Abel Martins Ferreira, chantre da mesma Sé». Archivo Eborense 1-11.

FonseCA, J. (1995-96): «Um motim da fome em Montemor-o-Novo em 1631». Almansor 13, pp. 109-12.

— (2002-2003): «A população do arcebispado de Évora em 1592». Callipole 10-11, pp. 33-47.

García Sanz, A. (1986): Desarrollo y crisis del Antiguo Régimen en Castilla la Vieja. Economía y sociedad en tierras de Segovia, 1500-1814. Madrid, Akal.

- (1990): «El sector agrario durante el siglo XvII: depresión y reajustes», in Jover Zamora (ed.), Historia de España Menéndez Pidal, vol.23. Madrid: Espasa-Calpe (2nd ed.), pp.159-235.

Godinho, V. Magalhães (1955): Prix et monnaies au Portugal, 1750-1850. Paris : École Pratique des Hautes Études, Armand Colin.

- (1970): Introdução à história económica. Lisbon: Livros Horizonte.

— (1978): «1580 e a Restauração», in Ensaios. Lisboa: Sá da Costa (2nd ed.), vol. 2, pp. 379-421.

Gurría García, P. A. (2004): «Dinámicas demográficas de La Rioja a partir de las series de bautismos, 1580-1900». Areas (24), pp. 67-82.

Hernández García, R. (2004): «La demografía de la provincia de Palencia a través de los bautismos». Areas (24), pp. 25-37.

Hoffman, P. T. (1991): «Un nouvel indice de la productivité agricole: les baux de NotreDame de Paris, 1450-1789». Histoire et Mesure 6 (3-4), pp. 215-43.

Justino, D. (1981): «Crises e ‘decadência’ da economia cerealífera alentejana no século xvIII. Contribuição para o seu estudo a partir da análise das séries dos preços regionais do trigo e da cevada (1684-1820)». Revista de História Económica e Social (7), pp. 2980.

Kamen, H. (1983): Spain in the later seventeenth century, 1665-1700. London: Longman.

LE Flem, J.-P. (1989): «Los aspectos económicos de la España moderna», in Manuel Tuñon de Lara (ed.), Historia de España. Barcelona: Labor, vol.5, pp. 11-127.

Lima, D. Pires De (1986): «Dois arcebispos da Casa de Bragança: D. Teotónio e D. Martinho de Portugal». Anais da Academia Portuguesa da História 31, pp. 53-102.

Llopis Agelán, E. and Cuervo Fuente, N. (2004): «El movimiento de población en la provincia de Ávila, 1580-1864». Areas (24), pp. 39-65. 
Magalhães, J. Romero (1976): «1637: motins da fome», off-print from Biblos (52).

- (1984): «O Algarve económico, 1600-1773». Coimbra: Universidade de Coimbra, Faculdade de Economia (doctoral thesis, mimeo).

Marín Barriguete, F. (1991): «La revuelta portuguesa de 1640 y sus consecuencias para la ganadería trashumante». Cuadernos de Historia Moderna y Contemporánea (11), pp. 195-207.

Moriceau, J.-M. and Postal-Vinay, G. (1992): Ferme, entreprise, famille. Grande exploitation et changements agricoles, $X V I I^{e}-{ }^{-X I} X^{e}$ siècles. Paris: EHESS.

NADAL, J. (1976): La población española (siglos XVI $a$ XX). Barcelona: Ariel (4th ed.).

OliveIRA, A. DE (1991): Poder e oposição política em Portugal no período filipino (15801640). Lisbon: Difel.

Pérez Moreda, V. (1980): Las crisis de mortalidad en la España interior. Siglos XVI-XIX. Madrid: Siglo Veintiuno.

Rodrigues, T. FERREIRA (1993): «As estruturas populacionais», in J. Romero Magalhães 